https://doi.org/10.11646/zootaxa.4500.1.2

http://zoobank.org/urn:lsid:zoobank.org:pub:DA7B9679-C66F-4768-A8D1-84BA1A992F64

\title{
Bearing the wrong identity: A case study of an Indo-Pacific common shallow water sponge of the genus Neopetrosia (Haplosclerida; Petrosiidae)
}

\author{
EDWIN SETIAWAN ${ }^{1, *}$, DIRK ERPENBECK ${ }^{1,2}$, GERT WÖRHEIDE ${ }^{1,2,3} \&$ NICOLE J. DE VOOGD $^{4,5,6}$ \\ ${ }^{I}$ Department of Earth and Environmental Science, Paleontology \& Geobiology, Ludwig-Maximilians-Universität München, Munich, \\ Germany. \\ ${ }^{2}$ GeoBio-Center, Ludwig-Maximilians-Universität München, Munich, Germany \\ ${ }^{3} S N S B$ - Bayerische Staatssammlung für Paläontologie und Geologie \\ ${ }^{4}$ Marine Biodiversity, Naturalis Biodiversity Center, Leiden the Netherlands \\ Institute of Environmental Sciences, Leiden University, Leiden, the Netherlands \\ ${ }^{6}$ Corresponding author.E-mail: Nicole.devoogd@naturalis.nl \\ "Present address: Zoology and Animal Engineering Lab, Department of Biology, Institut Teknologi Sepuluh November, Surabaya Indo- \\ nesia
}

\begin{abstract}
Sponges of the order Haplosclerida are often abundant and characteristic components of Indo-Pacific reefs, but are often misidentified, because of the lack of clear distinctive morphological characters. Neopetrosia exigua is an example of a haplosclerid sponge that is very common in Indonesian shallow coral reef environments but bears several different names. In the present study we investigated type material of several Indo-Pacific Neopetrosia species with a similar morphology and examined freshly collected specimen materials including specimens that are deposited at several institutions. In addition, we used molecular phylogenetic methods for assisting the morphological examinations. We conclude that the true identity of Neopetrosia exigua should be Neopetrosia chaliniformis. Likewise, $N$. exigua and $N$. pacifica should be considered as junior synonyms of $N$. chaliniformis. In conclusion, we advocate that molecular barcoding could significantly aid on sponge species' delimitation that possess limited morphological characters.
\end{abstract}

Key words: Porifera, Neopetrosia, type specimen, Indonesia, DNA barcoding

\section{Introduction}

Sponges are common and important elements of reef and mangrove communities in Indonesian marine ecosystems, where haplosclerid sponges are categorised as one of the most conspicuous orders due to their abundance in terms of diversity and quantity (Amir 1992, de Voogd 2004, de Voogd et al. 2004, de Voogd \& Cleary 2008, de Voogd \& van Soest 2002, van Soest 1989). However, the published knowledge of haplosclerids is far from complete (de Weerdt \& van Soest 2001). Taxonomically, haplosclerid sponges are recognised as one of the most complicated and unreliable groups in demosponges (Borchiellini et al 2004), and "a sound classification of the order is a long way from being established" (Redmond et al. 2011). For this reason, the use of classical taxonomy based on spicule dimensions, type and arrangement of skeletal meshes often fails in delimiting lower taxa and creates nonmonophyletic groups because of "vague and elusive morphological synapomorphies" within the suborders Haplosclerina and Petrosina (van Soest \& Hooper 2002). Moreover, current taxonomical rank of suborder Haplosclerina and Petrosina is abandoned, and Haplosclerida order rank is retained. In addition, a revision of Haplosclerida using added characters data is urged (Morrow \& Cardenas, 2015)

The genus Neopetrosia (family Petrosiidae) is an example of a haplosclerid genus that is very difficult to recognise and identify. De Laubenfels (1949) erected this genus for the previously described species Haliclona longleyi, although he did not define this new genus. The genus was further discussed by de Laubenfels (1954), Bergquist (1965), Wiedenmayer (1977), and van Soest (1980), but was only properly defined in 2002 (see Systema 
Porifera, Hooper \& van Soest 2002). The genus differs from other genera within the family Petrosiidae by its relatively small size of spicules and a recognisable anisotropic pattern in its skeleton (Desqueyroux-Faúndez \& Valentine 2002). So far, 32 nominal species have been recognised within Neopetrosia (World Porifera Database, van Soest et al. 2017).

Neopetrosia exigua (Kirkpatrick, 1900) is a very common species in many Indo-Pacific shallow water reefs and has extensively been mentioned in the literature, primarily for its interesting bioactive properties (Abdillah $e t$ al. 2013a,b, de Almeida Leone et al. 2008; Liu et al. 2004; Orabi et al. 2002). Neopetrosia exigua was originally described as Petrosia exigua from Christmas Island, Indian Ocean (south of Java, Indonesia) by Kirkpatrick (1900). He noted that the species possessed very small oxeas as opposed to its most closely allied species, Petrosia similis, Ridley \& Dendy 1886. Currently, two sponge taxa are accepted as junior synonyms of $N$. exigua, namely Neopetrosia pandora de Laubenfels, 1954 from Ponape (de Laubenfels 1954), Micronesia, and Xestospongia pacifica (Kelly-Borges \& Bergquist, 1988) from Motupore Island, Papua New Guinea (World Porifera Database, van Soest et al. 2017).

During our phylogeographic study, we observed a striking similarity between freshly collected specimens and Neopetrosia chaliniformis (Thiele, 1899) originally described as Petrosia chaliniformis. This species from Sulawesi, Indonesia was described one year before N. exigua, however, this name was never used subsequently after its original description. Here, we aim to unravel the true identity of these common shallow water Indo-Pacific sponges. We investigate type material and examine freshly collected specimen materials, including additional specimens that are deposited at several institutions. Main morphological characters such as spicule measurements and other skeleton features were recorded. In addition, molecular phylogenetic methods employing fragments of the mitochondrial cytochrome oxidase subunit $2(\operatorname{cox} 2)$ and 28S ribosomal DNA (28S rDNA) sequences are compared to supplement morphological examinations, since haplosclerids possess a reduced suite of phylogenetic informative characters (de Weerdt 1985).

\section{Materials and methods}

Data collection. Fourteen samples were freshly collected from several localities (West Java, North and South Sulawesi) in Indonesia. Directly after being collected, the samples were cut, rinsed and soaked in $98 \%$ ethanol before being preserved in $99 \%$ ethanol. Additional 18 samples were received from the Naturalis Biodiversity Center, Leiden, The Netherlands (samples coded with ZMAPOR, are at present the Zoological Museum Amsterdam collection housed in the Naturalis Biodiversity Center in Leiden), and further specimens were provided by the Queensland Museum (QM) Brisbane, Australia (G prefix). Holotype specimens were retrieved from the British Museum of Natural History, London, UK (BMNH, Neopetrosia exigua), the Zoological Museum Berlin, Germany (ZMB, Neopetrosia chaliniformis), the Smithsonian Museum, Washington DC, USA (USNM, Neopetrosia pandora), and the Australian Museum, Sydney, Australia (AM Z, Xestospongia pacifica) (see Table 1).

The descriptions presented below are based on external morphology, skeletal architecture and shape and size of the spicules. Spicule dimensions are given as the minimum-mean-maximum of length measurements $\mathrm{x}$ minimummean-maximum of width measurements from 25 spicule measurements. For study of the skeletal architecture, hand-cut perpendicular sections were made. These sections were air-dried, mounted in Ultrabed on a microscope slide, and studied under a Leica high power light microscope. Spicule preparations were made by dissolving a small piece of the specimen in commercial bleach, after which the residue was rinsed four times with water and once with $96 \%$ ethanol. The spicules were air-dried on microscopic slides and prepared for study with the light microscope by mounting them in Ultrabed.

Data Analyses. The statistical analyses were carried out using PASW 20.00 (SPSS Inc. 2012). The statistical significance of phenotypic differences among selected localities was tested by the Univariate analysis of variance (ANOVA, with Duncan's post hoc test, $\mathrm{p}<0.05$ ). These analyses were only conducted for some localities where at least three specimens were sampled (Thailand, West Java, North Sulawesi, South Sulawesi, Solomon Islands and the Great Barrier Reef Australia, see Table 1).

DNA extraction and sequencing. DNA extraction based on the previously published and established methods in sponge barcoding (Vargas et al. 2012) was performed for all specimens except the holotypes. Neopetrosia 
pandora and X. pacifica were extracted separately using the DNeasy Blood \& Tissue kit (Qiagen) following the instructions of the manufacturer. Because first attempts to amplify two $>100$-year-old holotypes (N. chaliniformis and $N$. exigua) failed, DNA extractions for those two holotypes were repeated using a modification from the CTAB phenol-chloroform method of Porebski et al. (1997). In this modified method, the phenol-octanol and RNase solutions steps were skipped. With this modified method we also gained amplifiable DNA for the two 100-year-old holotypes as opposed to the spin column method. The Polymerase Chain Reaction (PCR) using primers CO2F Por, 5'- TTTTTCACGATCAGATTATGTTTA-3' and CO2R Por, 5'-ATACTCGCACTGAGTTTGAATAGG-3' (Rua et al. 2011), was performed to amplify a fragment of the cox2 gene, and with primer 28S-C2-fwd, 5'GAAAAGAACTTTGRARAGAGAGT-3' and 28S-D2-rev and 5'- TCCGTGTTTCAAGACGGG-3' (Chombard et al. 1998) for a fragment of $28 \mathrm{~S}$ rDNA. The $25 \mu \mathrm{L}$ PCR mix consisted of $5 \mu \mathrm{L} 5 \mathrm{x}$ green GoTaq ${ }^{\circledR}$ PCR Buffer (Promega Corp, Madison, WI), $4 \mu \mathrm{L} 25 \mathrm{mM} \mathrm{MgCl}_{2}$ (Promega Corp, Madison, WI), $2 \mu \mathrm{L} 10 \mathrm{mM}$ dNTPs, $1 \mu \mathrm{L}$ each primer $(5 \mu \mathrm{M}), 9.8 \mu \mathrm{L}$ water, $2 \mu \mathrm{L}$ DNA template, and $0.2 \mu \mathrm{L}$ GoTaq ${ }^{\circledR}$ DNA polymerase $(5 \mathrm{u} / \mu \mathrm{l})$ (Promega Corp, Madison, WI). The PCR regime comprised an initial denaturation at $94^{\circ} \mathrm{C}$ for 3 minutes, 35 cycles of 30 seconds denaturation at $94^{\circ} \mathrm{C}, 20 \mathrm{~s}$ annealing at $40^{\circ} \mathrm{C}$ and $60 \mathrm{~s}$ elongation at $72^{\circ} \mathrm{C}$ each, followed by a final elongation at $72^{\circ} \mathrm{C}$ for $5 \mathrm{~min}$. For the holotypes of $N$. chaliniformis and N. exigua $2 \mu \mathrm{L}$ Bovine Serum Albumin (BSA $10 \mathrm{mg} / \mathrm{ml}$ ) were added in the PCR mix and PCR regime was modified with $45 \mathrm{~s}$ annealing at $40^{\circ} \mathrm{C}, 45 \mathrm{~s}$ elongation at $72^{\circ} \mathrm{C}$ each and a final elongation at $72^{\circ} \mathrm{C}$ for $7.5 \mathrm{~min}$. All of the PCR products were cleaned with the ammonium acetate precipitation method. Sequencing of the forward and reverse strand was performed with the ABI BigDye v3.1 (Applied Biosystems, California USA) chemistry and the amplification primers following the manufacturer's protocol on an ABI 3730 Automated Sequencer in the Genomic Sequencing Unit of LMU Munich (http:// www.gi.bio.lmu.de/sequencing/). All sequences are deposited at NCBI GenBank under accession numbers KM030095-KM030106, KM030107-KM030118 (cox2 mtDNA) and KM030120-KM030128, KM030130KM030145 (28S rDNA fragment C2-D2).

Molecular Phylogenetic Analysis. Geneious version 6.1.7, (http://www.geneious.com) was used for assembling, trimming and analysing the sequences. Additionally, sequences were checked with BLAST against GenBank (http://www.ncbi.nlm.nih.gov/) for contaminations. Sequences were aligned with MUSCLE version 3.5 program (Edgar 2004) as implemented in Geneious under default settings. Phylogenetic reconstructions with cladistic analyses under probabilistic criteria were inferred for cox 2 sequences using Bayesian Inferences (BI) and Maximum Likelihood (ML). The HKY+ I model of evolution as suggested by jModeltest v. 2.1.3 (Darriba et al. 2012) under the Akaike Information Criterion (Akaike 1974) was selected. BI was performed in MrBayes v. 3.2.1 (Ronquist et al. 2012). Each analysis consisted of two independent runs of four Metropolis-coupled Markov-chains under default temperature with trees sampled at every $1000^{\text {th }}$ generation. Analyses were terminated automatically when the chains converged significantly as indicated by an average standard deviation of split frequencies $<0.01$. Similarly ML analyses were inferred using RAxML v. 7.0.4 in the raxmlGUI v. 1.3 program (Silvestro \& Michalak 2012) with a rapid bootstrap of 1000 replications (Stamatakis et al. 2008). As the HKY+ I model is not implemented in RAxML, the model utilised in RAxML was changed to GTR+ I (Stamatakis 2008).

Cladistic analyses were not performed for the 28S rDNA sequences because an unambiguous final alignment was not possible due to the abundance of highly variable sites. Therefore, a simple phenetic analysis was carried out instead to display the grade of similarities between the sequences. For this purpose a data set of the 28S rDNA sequences was approached using MUSCLE (Edgar 2004) under default settings and analyzed with NeighbourJoining (NJ) analysis with observed distances in SeaView version 4.4.2 (Gouy et al. 2010).

A sample of $X$. testudinaria (Lamarck, 1815) (GW1341: Indonesia, Central Java, Kep Karimun Jawa, Pulau Sintok, South side, $5^{\circ} 47^{\prime} 06^{\prime \prime} \mathrm{S}, 110^{\circ} 30^{\prime} 18^{\prime \prime}$ E, 27 May 2011, coll. E. Setiawan) was sequenced (KM 030119) and utilised only for the molecular analysis as additional non-Neopetrosia sequence in cox 2 mtDNA phylogenetic analysis. We excluded molecular phylogeny analyses of samples from localities and sites that consist of less than three specimens, i.e., Northern Territory, Singapore, Palau (see details Table. 1). 


\section{Results}

\section{Systematics}

Phylum Porifera Grant, 1835

Class Demospongiae Sollas, 1885

\section{Order Haplosclerida Topsent, 1928}

\section{Family Petrosiidae van Soest, 1980}

\section{Genus Neopetrosia de Laubenfels, 1949}

Syn. Densa de Laubenfels, 1934

Definition: Petrosiidae with finely hispid surface produced by fine brushes of oxeas issued from subectosomal tracts, and a compact choanosomal network combining rounded meshes with a superimposed anisotropic reticulation. Megascleres oxeas less than $200 \mathrm{fLm}$ long (Desqueyroux-Faundez \& Valentine 2002).

\section{Neopetrosia chaliniformis (Thiele, 1899)}

Figure 1A, 2A, 3A, Table 1

Petrosia chaliniformis Thiele, 1899: 21, Pl. 2, Fig. 9; Pl. 5, Fig. 15

Material examined: Holotype: ZMB2889, Indonesia, North Sulawesi, Kema, Minahasa.

Description (amended from Thiele 1899): Sponge consists of several fragments. Frequently found in the form like plates with branches. Branches have a diameter of 5- $6 \mathrm{~mm}$. Size of osculum is measured 1-2 mm. Height is measured in average of $12 \mathrm{~cm}$.

Consistency. Hard to touch, crumbly.

Colour. Chocolate brown and light brown in alcohol.

Skeleton. Skeleton has structure of isodictyal tangential spicule network with one size of spicule.

Spicules. Oxeas in a range of 100-140.8-165 $\mu \mathrm{m}$ x 7.5-9.9 -12.5 $\mu \mathrm{m}$.

Remarks: Thiele (1899) remarked that the specimen was more properly related to the genus Petrosia rather than in Pellina because it has an easy removable epidermal layer, however he was not certain about placing the specimen in the genus Petrosia because its consistency was more elastic than in typical Petrosia. Likewise, Thiele observed that the skeletal structure of the specimen is similar to that of Reniera or Rhizochalina. Nevertheless, similarities between genera mentioned by Thiele are no longer relevant given that Reniera and Pellina were transferred to several genera within the family Petrosiidae e.g., Petrosia, Haliclona, Rhizochalina (the latter renamed Oceanapia, World Porifera Database, van Soest et al. 2017).

\section{Neopetrosia exigua (Kirkpatrick, 1900)}

Figure 1B, 2B, 3B, Table 1

Petrosia exigua Kirkpatrick, 1900: 139, Pl, XII, Fig. 7, Pl. XIII, Fig. 4

Material examined: Holotype: BMNH1898.12.20.49, Australia, Christmas Island, Indian Ocean.

Description (amended from Kirkpatrick 1900): Sponge forms a hard, thick, nodulated crust, smooth surface, showing an irregular reticulate pattern formed by pore-areas, oscules are measured in a range of $1-5 \mathrm{~mm}$ in diameter.

Colour. Pale gray brown in the dry condition.

Skeleton. Forms of slender main lines of fibres passing vertically to the surface and connected at right angles to this plane by closely packed single spicules, so as to form circular or obscurely polygonal tubes about $70 \mathrm{~mm}$ in diameter. The skeletal network is dense and irregularly oriented. 
Spicules. Oxeas in a size range of 70-113.8-130 x 5-7.3-10 $\mu \mathrm{m}$.

Remarks: Kirkpatrick (1900) remarked that spicules are considerably smaller than the allied species Petrosia similis (less than half the size). We also discovered that only a very small fragment of the type material is left in the BMNH collections.

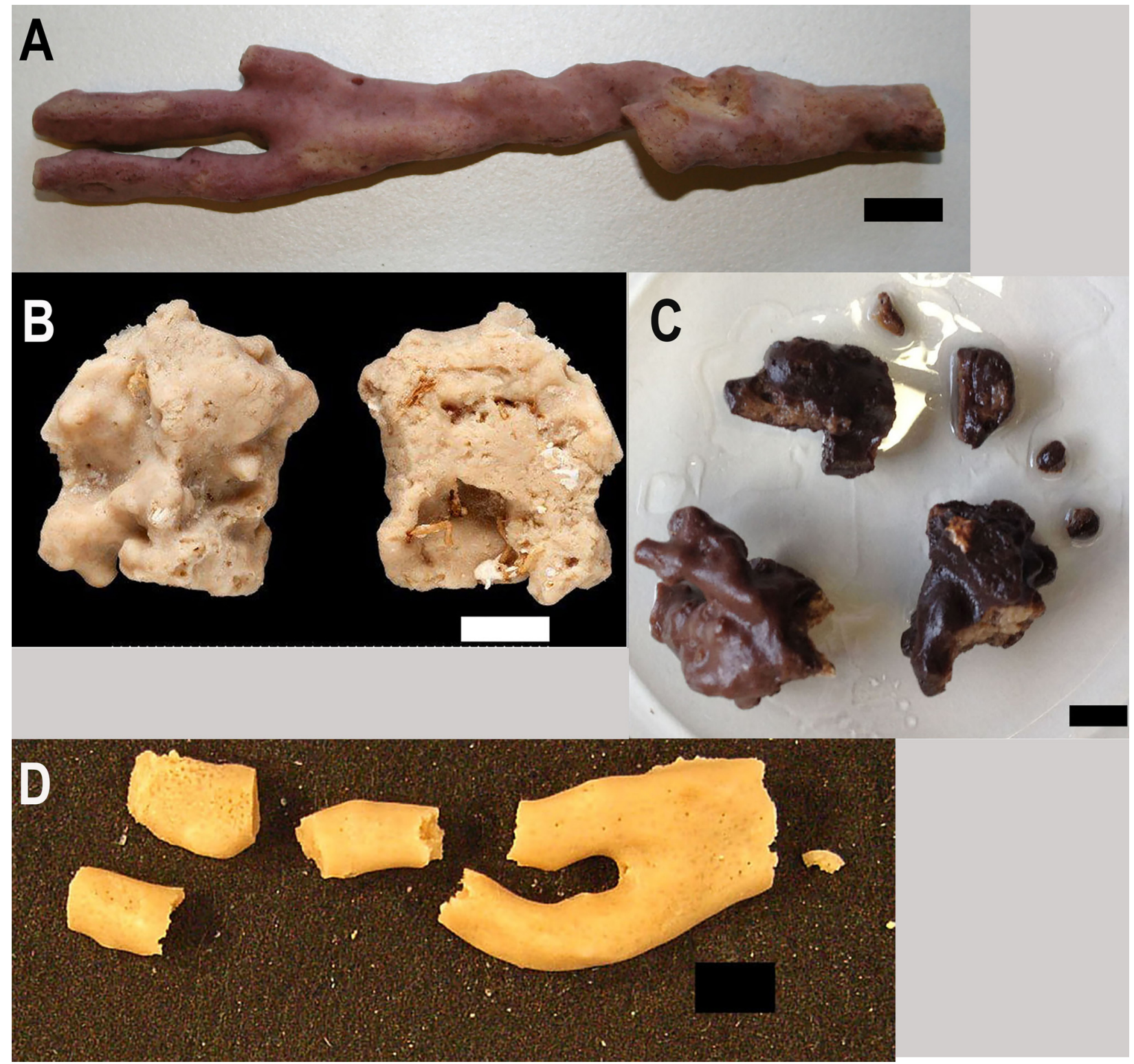

FIGURE 1. A Neopetrosia chaliniformis (Thiele, 1899) holotype ZMB2889, B Neopetrosia exigua (Kirkpatrick, 1901), holotype BMNH1898.12.20.49, C Xestospongia pacifica Kelly-Borges \& Bergquist, holotype AM Z4999, and D Neopetrosia pandora de Laubenfels, 1954, holotype USNM4806. Scale bar $=1 \mathrm{~cm}$.

\section{Xestospongia pacifica Kelly-Borges \& Bergquist, 1988}

Figure $1 \mathrm{C}, 2 \mathrm{C}, 3 \mathrm{C}$, Table 1;

Xestospongia pacifica Kelly-Borges \& Bergquist, 1988: 155, P. 6c, 6d.

Material examined: Holotype: AM Z4999, Papua New Guinea, Buna Motu Reef, Bootless Bay, South Papua New Guinea.

Description (amended from Kelly-Borges \& Bergquist 1988): The sponge grows as an encrustation of 5-10 $\mathrm{mm}$ thickness, frequently with papillae 20-60 $\mathrm{mm}$ high and 5-10 wide. It has small oscules of 1-3 $\mathrm{mm}$ width. 
Colour. In life, the colour is brownish orange to olive. In alcohol, the colour changes into olive black and slightly browner.

Consistency. Tough, compressible and extremely brittle.

Spicules. Oxeas in a size range of 100-149.6-175 x 5-9.2-10 $\mu \mathrm{m}$

Skeleton. Dense and an isodictyal tangential spicule network with one size of spicules.

Remarks: This species was synonymised with Neopetrosia exigua by Van Soest (2008) based on morphological similarities. These include the spicule consisting only of oxeas smaller than $200 \mu \mathrm{m}$ and the skeletal meshes are more compact in structure than those of Xestospongia (Desqueyroux-Faundez \& Valentine 2002).

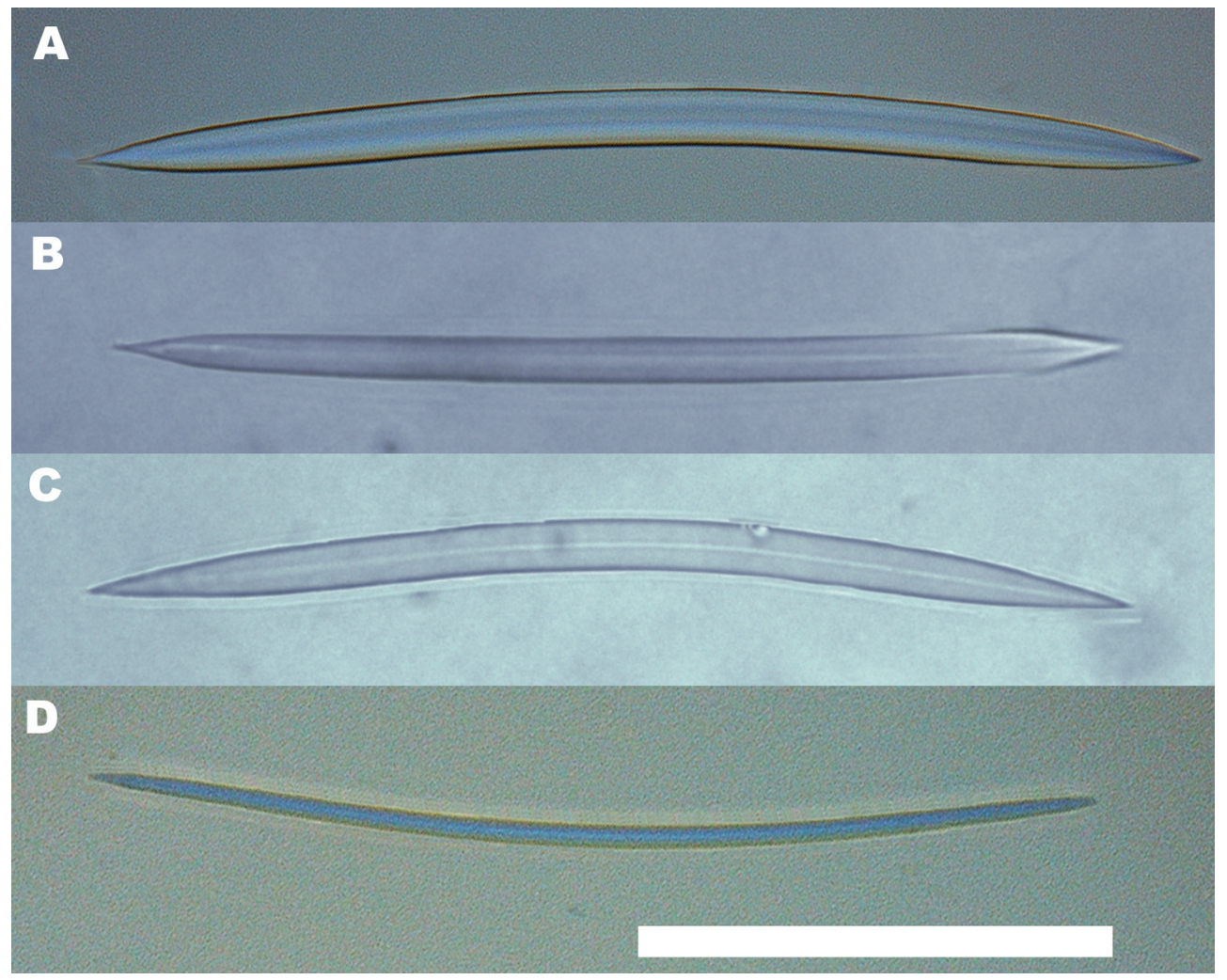

FIGURE 2. Oxea from the holotypes of A Neopetrosia chaliniformis (Thiele, 1899) ZMB2889, B Neopetrosia exigua (Kirkpatrick, 1901), BMNH1898.12.20.49, C Xestospongia pacifica Kelly-Borges \& Bergquist, AMS Z4999, and D Neopetrosia pandora de Laubenfels, 1954, USNM4806. Scale bar $=50 \mu \mathrm{m}$

\section{Neopetrosia pandora de Laubenfels, 1954}

Figure 1D, 2D, 3D, Table 1

Neopetrosia pandora de Laubenfels, 1954: 81, Fig. 49.

Material examined: Holotype: USNM 23046, Palau, Matalim, East Ponape, 1 August 1949, $5 \mathrm{~m}$ depth, coll. M.W. de Laubenfels.

Description (amended from de Laubenfels 1954): A repent or sprawling ramose sponge, reaching a maximum length of at least $13 \mathrm{~cm}$. The diameter of the branches is $9 \mathrm{~mm}$; oscules are about $2 \mathrm{~mm}$ in diameter and $2 \mathrm{~cm}$ apart.

Colour. Colour in life is dull olive drab.

Consistency. Slightly spongy but also somewhat stiff, tearing very easily.

Spicules. Oxeas in a range of 100-119.8-150 x 2.5-2.9-5 $\mu \mathrm{m}$.

Skeleton. Less dense, more irregular isodictyal spicule network with one size of spicule.

Remarks: De Laubenfels (1954) described that the consistency of the type specimen was slightly spongy, somewhat stiff and tearing very easily. The surface of the type specimen does not possess an ectosomal specialisation, which is a typical characteristic of sponges from Family Chalinidae. Little or lack of spongin in 
skeleton was observed. The spicules are also much thinner than the other spicules of type specimens and samples analysed in this study.
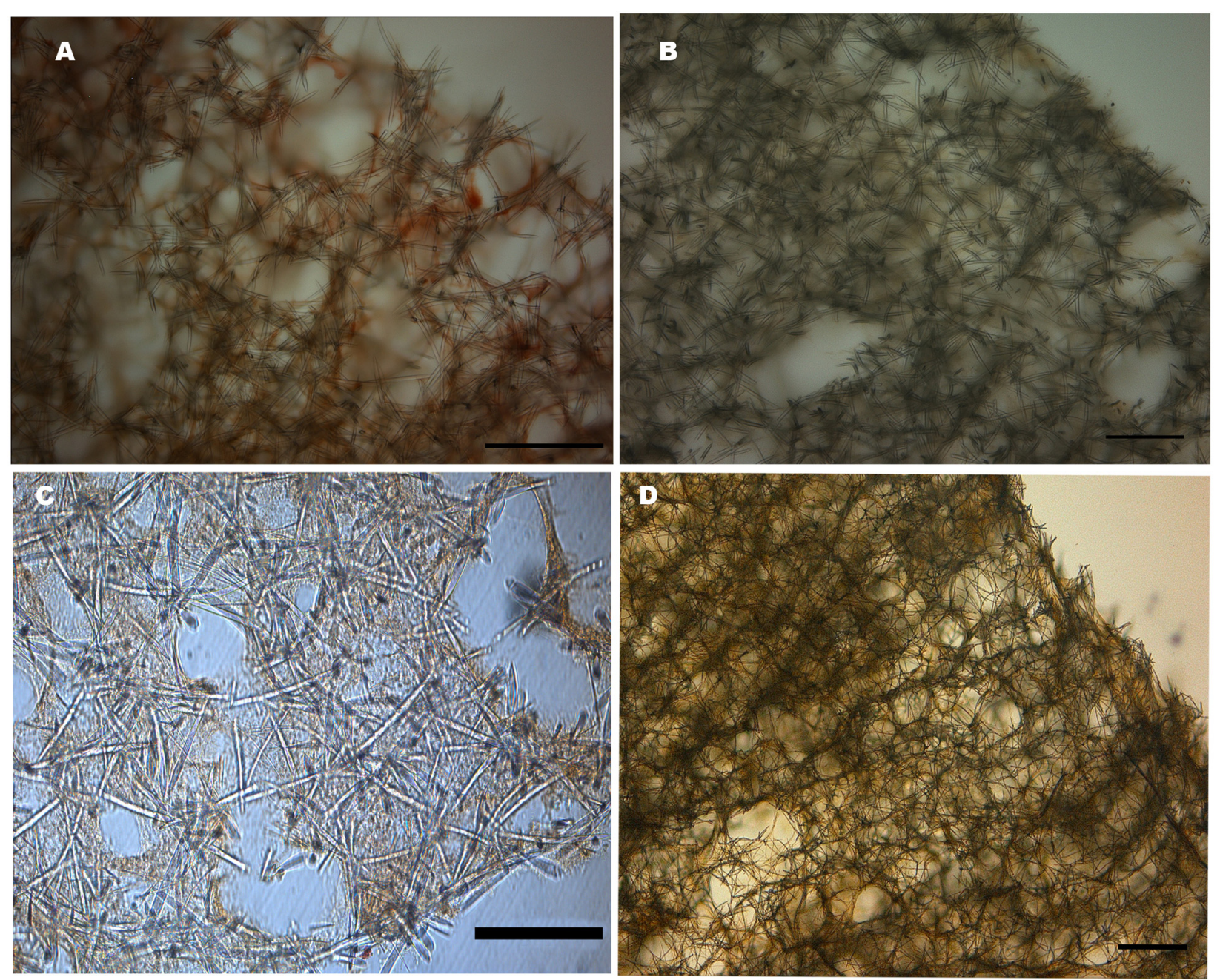

FIGURE 3. Spicule arrangement in holotypes of A Neopetrosia chaliniformis (Thiele, 1899) ZMB2889, B Neopetrosia exigua (Kirkpatrick, 1901), BMNH1898.12.20.49, C Xestospongia pacifica Kelly-Borges \& Bergquist, AMS Z4999, and D Neopetrosia pandora de Laubenfels, 1954, USNM4806. Scale bar $=150 \mu \mathrm{m}$.

\section{Additional material examined}

We examined additional material identified as Neopetrosia exigua) and freshly collected specimens identified as Neopetrosia chaliniformis from various location in Mauritius, Thailand, Japan, the Philippines, Singapore, Indonesia, Palau, Papua New Guinea, Australia, Solomon Islands, Vanuatu, Palau, and Tonga (see detail below, Table 1 and Figure 4 A-C).

QM G303302 (GW18429): Australia, Northern Territory, Dudley Point Reef, East Point, Darwin, intertidal reef, $12^{\circ} 25^{\prime} 03^{\prime \prime} \mathrm{S}, 130^{\circ} 49^{\prime} 00^{\prime \prime} \mathrm{E}, 20$ September 1993, coll. JNA Hooper; QM G313113 (GW18478): Singapore, Pulau Tembakul (Kusu I), Freyberg Channel, very silty patchy coral reef, 1 13' 05" N, 103 51' 07" E, 2 May 1995, 18.7m depth, coll. JNA Hooper; QM G313297 (GW18491): Tonga, Vaipuua, at end of channel, highly silted fringing reef, Porites spires, $18^{\circ} 37^{\prime} 55^{\prime \prime} \mathrm{S}, 173^{\circ} 58^{\prime} 47^{\prime \prime} \mathrm{W}, 14$ November 1997, $15 \mathrm{~m}$ depth, coll. JNA Hooper; QM G306321 (GW 18598); Palau, Ongingiang, W of, W. Palau, fringing coral reef surrounding channel in outer barrier reef, strong current, spur and grooves, $7^{\circ} 16^{\prime} 05^{\prime \prime} \mathrm{N}, 134^{\circ} 14^{\prime} 05^{\prime \prime} \mathrm{E}, 10$ December 1995, $31 \mathrm{~m}$ depth, coll. JNA Hooper; QM G311804 (GW18777): Papua New Guinea, North of Lion Island, S/w Of Motupore Island; Near Port 
Moresby, PNG, top ridge or reef, dead coral, 19 September 1990, 6-18m depths, coll. JNA Hooper; QM G315226 (GW18793): Australia, Queensland, Hook Reef lagoon, coral reef lagoon, 19 45' 14" S, 149 $19^{\circ} 45^{\prime \prime}$ E, 5 June 1999, 9.4m depth, coll. JNA Hooper; QM G312397 (GW 18804): Australia, Western Australia, North Head,

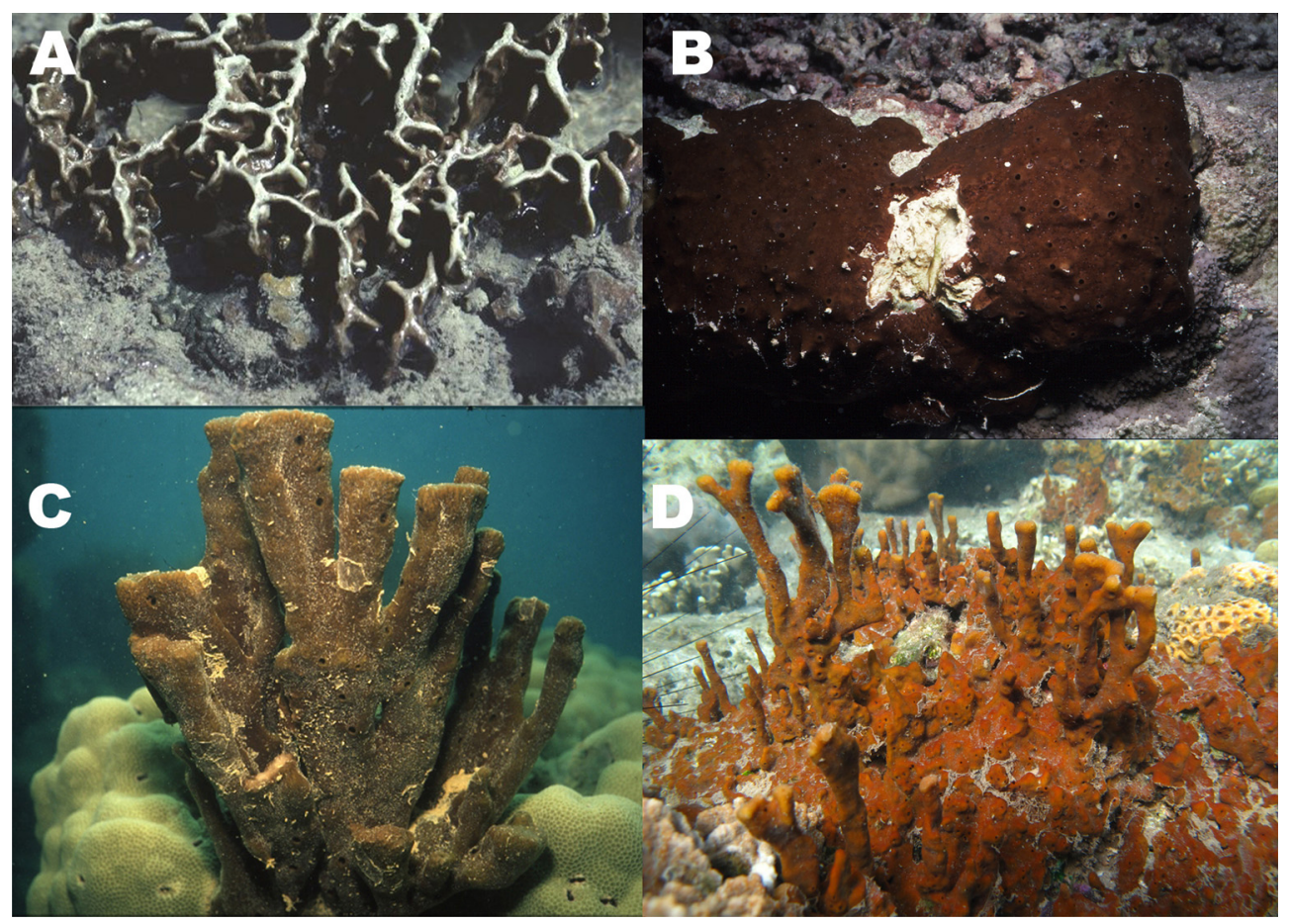

FIGURE 4. In situ photo of sponges identified as $N$. exigua, that were collected in (A) Northern Territory Australia, QM G303302, (B) Palau, QM G306321, (C) Tonga, QM G313297 and (D) a sponge identified as N. chaliniformis that was photographed in Probolinggo, East Java, Indonesia.

Beagle Bay, NW WA, rock salt , 16³0' 00" S, 122 19' 12" E, 12 August 1991, coll. JNA Hooper; QM G315374 (GW18806): Australia, Queensland, Stevens Reef, GBR, back reef, 20 32' 34" S, 150 6' 26" E, 7 June 1999, 30m depth, coll. JNA Hooper; QM G322668 (GW 19027): Solomon Islands, Rendova Island Tetepare, Fringing reef, inshore slope northwest side, $8^{\circ} 42^{\prime} 04^{\prime \prime} \mathrm{S}, 157^{\circ} 28^{\prime} 14^{\prime \prime}$ E, 6 July 2009, 20-50m depth, coll. JNA Hooper; QM G322710 (GW 19041): Solomon Islands, Rendova Island Tetepare, Fringing reef, inshore slope northwest side, $8^{\circ}$ 42' 04" S, 157 28' 14" E, 6 July 2009, 40-50m depth, coll. JNA Hooper; QM G322696 (GW19052): Solomon Islands, Vangunu Island, Barrier reef, external slope of slope facing northwest vertical wall, richly covered with various organisms, $8^{\circ} 40^{\prime} 19^{\prime \prime} \mathrm{S}, 157^{\circ} 50^{\prime} 15^{\prime \prime} \mathrm{E}, 5$ July 2009, coll. JNA Hooper; GW2037: Indonesia, West Java, Thousand Island, JAK01- Pulau Air, 5० 45' 35" S, $106^{\circ} 34^{\prime} 44^{\prime \prime}$ E, 26 July 2011, coll. N.J de Voogd; GW2112: Indonesia, West Java, Thousand Island, JAK03 - Semak Daun NW, 5 43' 40" S, 106 33' 57" E, 26 July 2011, 16m depth, coll. N.J de Voogd; GW2113: Indonesia, West Java, Thousand Island, JAK03 - Semak Daun NW, $5^{\circ} 43^{\prime} 40^{\prime \prime}$ S, $106^{\circ} 33^{\prime}$ 57" E, 26 July 2011, 16m depth, coll. N.J de Voogd; QM G315299 (GW 18758): Australia, Queensland, Edgell Reef, back reef, 20 8' 53" S, 149 55' 09" E, 6 June 1999, 18m depth, coll. JNA Hooper; ZMA POR16482

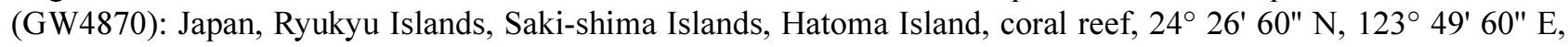
coll. K. Watanabe; GW4782: Indonesia, N Sulawesi, Lembeh, W Sarena Kecil, $1^{\circ} 27^{\prime} 25.5234^{\prime \prime N}, 125^{\circ} 13^{\prime}$ 31.1874"S, 17 Feb 2012, coll. N.J de Voogd; GW4783: Indonesia, N Sulawesi, Lembeh, Tanjung Nanas I, $1^{\circ} 27^{\prime}$ 40.212"N, 125 13' 36.408"S, 3 Feb 2012, coll. N.J de Voogd; GW4784: Indonesia, N Sulawesi, Lembeh, Tanjung Kelapasatu, $1^{\circ} 25^{\prime} 38.568^{\prime \prime N}, 125^{\circ} 11^{\prime} 0.7794 " S, 15$ Feb 2012, coll. N.J de Voogd; GW4785: Indonesia, N Sulawesi, Lembeh, N Tanjung Pandean, $1^{\circ} 24^{\prime} 21.7074 " N, 125^{\circ} 10^{\prime} 4.5114 " S, 14$ Feb 2012, coll. N.J de Voogd; GW4788: Indonesia, N Sulawesi, Lembeh, S Pulau Dua, $1^{\circ} 23^{\prime} 17.016^{\prime \prime N}, 125^{\circ} 12^{\prime} 43.1274 " S, 13$ Feb 2012, coll. N.J de Voogd; ZMA POR16473 (GW4811): Palau, Koror Island, Abe's Traverse, smooth; ZMA POR21753 (GW4828): Philippines, Calamian Group: Busuanga Island; ZMA POR21752 (GW4829): Philippines, Calamian Group: Busuanga Island; ZMA POR18793 (GW4843): Thailand, Laem Tum-Pung, South of Ko Kram, Sattahip, Chonburi, rock, 25 February 2007, coll. Sumaitt Putchakarn; ZMA POR18754 (GW4845): Thailand, South of Ko Mark, Chang Islands, Trad, rock, $11^{\circ} 47^{\prime} 10^{\prime \prime} \mathrm{N}, 102^{\circ} 29^{\prime} 14^{\prime \prime} \mathrm{E}, 8$ August 2012, coll. Sumaitt Putchakarn; ZMA POR18737 (GW4849): Thailand, West side of Ko Klum, Chang Islands, Trad, rock, $11^{\circ} 55^{\prime} 02^{\prime \prime} \mathrm{N}, 102^{\circ} 21^{\prime} 43^{\prime \prime} \mathrm{E}$, 8 August 2012, coll. Sumaitt Putchakarn; ZMA POR17251 (GW4866): Mauritius, 25 June 2006, identified by D. 
Marie; ZMA POR17229 (GW4867): Indonesia, South Sulawesi, Makassar, 8 May 2012, identified by R.A. Edrada; GW7173: Indonesia, South Sulawesi, Barangbaringan, 5 2' 59.60"S, 119 25' 12"E, 5 Aug 2012; GW7174: Indonesia, South Sulawesi, Barangbaringan, 5 2' 59.60"S, 119 25' 12"E, 5 Aug 2012; GW7175: Indonesia, South Sulawesi, Lankai, 5 1' 44.7"S, 119 5' 8.8" E, 8 Aug 2012.

Comments: The length of oxeas overlap among the type specimens of $N$. chaliniformis, $N$. exigua, X. pacifica and most of the additional analysed material. Conversely, the oxeas from the type of $N$. pandora and specimens identified as $N$. exigua from the Great Barrier Reef, Australia are much thinner (Table 1). Further statistical tests based on the 20 collected samples from six localities (Thailand, West Java, North Sulawesi, Southeast Sulawesi, Great Barrier Reef and Solomon Islands) revealed that there was a significant difference in spicule lengths $(0.005$, $\mathrm{p}<0.05)$ and widths $(0.001, \mathrm{p}<0.05)$ from each locality.

The spicule arrangement of Neopetrosia chaliniformis, N. exigua, and Xestospongia pacifica types is similar (Figure 3A, B, C), sharing a high degree of skeletal density and possessing an isodictyal tangential skeleton. On the other hand, the type specimen of $N$. pandora exhibited a less dense spicular network and more irregular spicule arrangement despite its similarity to an isodictyal tangential skeleton (Figure 3D).

\section{Molecular phylogenetic analyses}

Only the 28S rDNA sequences from one type specimen ( $N$. pacifica) could be generated.). Furthermore, the cox2 mtDNA fragments were successfully amplified in three type specimens; $N$. chaliniformis, $N$. exigua and $N$. pacifica (see Table 1). The cox 2 alignment length with all taxa included was 350 base pairs with 129 variable sites.

The sequences number in the 28S rDNA phylogenetic tree increased because three individuals (G315229, GW2037, and GW2113) consist of two sequence types. In order to resolve the sequence type ambiguities, SeqPHASE (Flot 2010) were implemented. The alignment length for the $28 \mathrm{~S}$ sequences was 606 characters. It comprises only $69 \%$ alignable characters from the one holotype, collected specimens, and outgroups.

The resulting trees are shown in Figures 5 and 6 . The cox 2 holotype sequences from $N$ chaliniformis, $N$. exigua, and $X$. pacifica were identical. This sequence type is shared with several other samples collected in the field, which is corroborated in the $28 \mathrm{~S}$ rDNA analyses.

\section{Proposed Nomenclatural Acts}

Synonymise Petrosia chaliniformis Thiele, 1899, Petrosia exigua Kirkpatrick, 1900, and Xestospongia pacifica Kelly-Borges \& Bergquist, 1988, with the former being the senior available name for the taxon Neopetrosia chaliniformis (Thiele, 1899).

\section{Discussion}

The morphology is important for distinguishing sponge species within the family Petrosiidae. In general, all holotypes and other collected samples examined in this study have an overall encrusting appearance and occasionally possessing branches. Likewise, all of those specimens possess a dark to light brown colouration, a sticky texture, and a brittle and compressible consistency that relate to the field characteristics of Neopetrosia species. We conclude that $N$. chaliniformis and $N$. exigua are the same species based on both morphological and genetic analyses. The former species name was described only one year before $N$. exigua (Kirkpatrick 1900, Thiele 1899, Van Soest et al. 2014). Thus, based on the principle of priority of the ICZN (2015), N. chaliniformis is the valid name and $N$. exigua is its junior synonym. The type material of $N$. chaliniformis is well recognizable and conforms to recent freshly collected material of this species, whereas the material of $N$. exigua is only a small fragment of a crust. It is difficult to identify haplosclerid sponges and misidentifications are frequent, further exacerbated by incomplete descriptions or inadequate illustrations depicting key characters, leading to the plethora of synonyms amongst many nominal species.

Growth forms are frequently regarded as being static (only encrusting or only branching species), but in situ observations revealed that encrusting species (assumed as $N$. exigua) forms branches under certain circumstances (cf. N. chaliniformis). This species is encrusting most of the time but forms branches occasionally (Figure $4 \mathrm{~A}-\mathrm{D}$ ). 


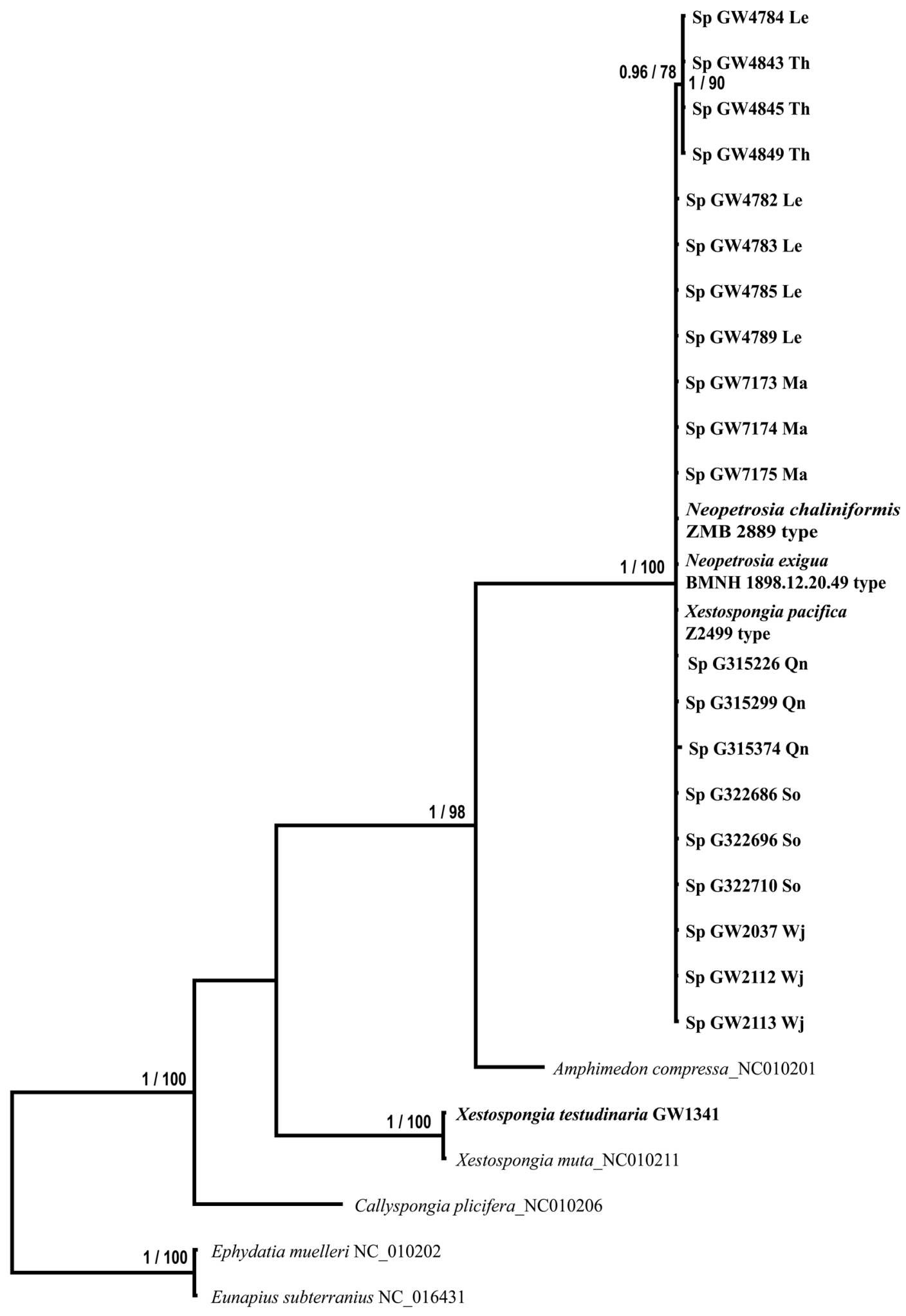

0.06

FIGURE 5. Bayesian cox 2 phylogram of Neopetrosia spp. Numbers on the branches represent posterior probabilities (PP) / bootstrap proportions (BP) of maximum likelihood analyses. Scale bar indicates the number of substitutions per site. Bold is sequences, which are obtained from this study. $\mathrm{Wj}=$ Pulau Seribu, West Java, Indonesia, Indonesia Le $=$ Lembeh, North Sulawesi, Indonesia, $\mathrm{Ma}=$ Makassar, South Sulawesi, Indonesia $\mathrm{Th}=$ Southeast Thailand, $\mathrm{Q} n=$ The Great Barrier Reef, Queensland, Australia, $\mathrm{So}=$ Solomon Islands 


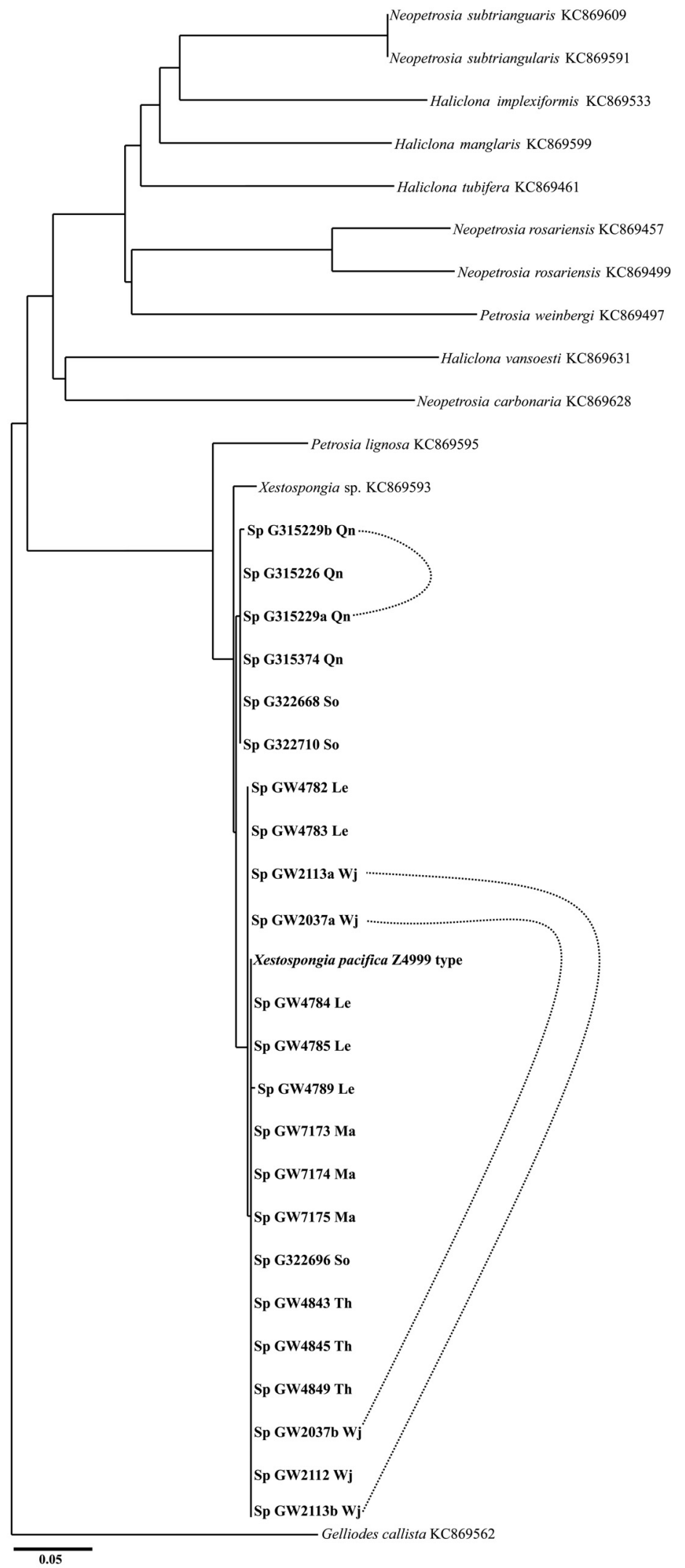

FIGURE 6. Neighbor Joining phylogram of 28S rDNA sequences from Neopetrosia spp. The scale bar indicates the number of substitutions per site and dashed lines indicate connectivity between two sequence types from one individual. Bold are sequences, which are obtained from this study. Wj= Pulau Seribu, West Java, Indonesia, Le= Lembeh, North Sulawesi, Indonesia, $\mathrm{Ma}=$ Makassar, South Sulawesi, Indonesia $\mathrm{Th}=$ Southeast Thailand, $\mathrm{Qn}=$ The Great Barrier Reef, Queensland, Australia, $\mathrm{So}=$ Solomon Islands. 
TABLE 1. TABLE 1 . Neopetrosia spp. examined in this study $(X=$ could not be amplified its DNA, $*=$ two sequence types, $X X=$ excluded from Molecular Phylogeny Analyses). GW vouchers numbers are also official Museum Numbers of the Bavarian State collection for Paleontology and Geology as SNSB-BSPG.GWXXXXX.

\begin{tabular}{|c|c|c|c|c|c|c|}
\hline $\begin{array}{l}\text { Voucher } \\
\text { Numbers }\end{array}$ & Museum code & Length $(\mu \mathrm{m})$ & Width $(\mu \mathrm{m})$ & Localities & $\begin{array}{l}\text { Cox2 } \\
\text { Genbank } \\
\text { accession } \\
\text { numbers }\end{array}$ & $\begin{array}{l}\text { 28S rDNA } \\
\text { Genbank } \\
\text { accession } \\
\text { numbers }\end{array}$ \\
\hline GW7107 & $\begin{array}{l}\text { ZMB2889 } \\
\text { (Holotype } N . \\
\text { chaliniformis) }\end{array}$ & $100-\mathbf{1 4 0 . 8}-165$ & $7.5-9.9-12.5$ & $\begin{array}{l}\text { North Sulawesi, } \\
\text { Indonesia }\end{array}$ & KM030103 & $\mathrm{X}$ \\
\hline GW7185 & $\begin{array}{l}\text { BMNH1898.12.20.49 } \\
\text { (Holotype } N . \text { exigua) }\end{array}$ & $70-113.8-130$ & $5-7.3-10$ & $\begin{array}{l}\text { Christmas Island, } \\
\text { Australia }\end{array}$ & KM030104 & $\mathrm{X}$ \\
\hline GW4805 & $\begin{array}{l}\text { Z4999 } \\
\text { (Holotype N. pacifica) }\end{array}$ & $100-\mathbf{1 4 9 . 6}-175$ & $5-9.2-10$ & $\begin{array}{l}\text { Bootless Bay } \\
\text { Papua New Guinea }\end{array}$ & KM030105 & KM030128 \\
\hline GW4806 & $\begin{array}{l}\text { USNM23046 } \\
\text { (Holotype } N \text {. pandora) }\end{array}$ & 100-119.8-150 & $2.5-2.9-5$ & East Ponape, Palau & $\mathrm{X}$ & $\mathrm{X}$ \\
\hline GW4843 & & $110-\mathbf{1 3 6 . 8}-155$ & $5-6.1-7.5$ & Southeast Thailand & KM030113 & KM030137 \\
\hline GW4845 & & $100-\mathbf{1 3 4 . 4}-155$ & $5-6.3-7.5$ & & KM030114 & KM030138 \\
\hline GW4849 & & $100-\mathbf{1 3 7 . 2}-160$ & $5-7.6-10$ & & KM030115 & KM030139 \\
\hline GW2037 & & $100-\mathbf{1 3 8 . 8}-170$ & $5-7.4-7.5$ & $\begin{array}{l}\text { Thousand Island, } \\
\text { West Java }\end{array}$ & KM030116 & $\begin{array}{l}\text { KM030140 } \\
\text { KM030141* }\end{array}$ \\
\hline GW2112 & & $110-\mathbf{1 5 1 . 8}-170$ & $5-7.3-10$ & Indonesia & KM030117 & KM030142 \\
\hline GW2113 & & 100-140.2-175 & $5-7.3-7.5$ & & KM030118 & $\begin{array}{l}\text { KM030143 } \\
\text { KM030144* }\end{array}$ \\
\hline GW4782 & & $110-141-160$ & $5-8-10$ & Lembeh, North & KM030095 & KM030120 \\
\hline GW4783 & & $120-146.4-175$ & $7.5-7.8-10$ & Sulawesi & KM030096 & KM030121 \\
\hline GW4784 & & $105-148-175$ & $5-7.6-10$ & & KM030097 & KM030122 \\
\hline GW4785 & & 100-144.2-175 & $7.5-8.2-10$ & & KM030098 & KM030123 \\
\hline GW4788 & & 110-141.6-155 & $5-\mathbf{5 . 4}-7.5$ & & KM030099 & KM030124 \\
\hline & & $125-\mathbf{1 5 1 . 8}-175$ & $5-7.3-10$ & Makassar, South & KM030100 & KM030125 \\
\hline GW7173 & & & & Sulawesi & & \\
\hline GW7174 & & $100-\mathbf{1 3 4 . 8}-175$ & $5-7.5-10$ & & KM030101 & KM030126 \\
\hline GW7175 & & 80-141.6-155 & $5-5.4-7.5$ & & KM030102 & KM030127 \\
\hline GW18793 & G315226 & $95-\mathbf{1 1 2 . 8}-130$ & $2.5-4.9-5$ & GBR, Australia & KM030107 & KM030130 \\
\hline GW18758 & G315299 & $80-119.8-150$ & $2.5-4.9-5$ & & KM030108 & $\begin{array}{l}\text { KM030131 } \\
\text { KM030132* }\end{array}$ \\
\hline GW18806 & G315374 & $100-\mathbf{1 2 8 . 6}-150$ & $2.5-4.5-5$ & & KM030109 & KM030133 \\
\hline GW 19027 & G322668 & 100-137.4-150 & $5-5.6-7.5$ & Solomon Islands & KM030110 & KM030134 \\
\hline GW19052 & G322696 & $100-\mathbf{1 2 9 . 8}-150$ & $2.5-5-7.5$ & & KM030111 & KM030135 \\
\hline GW19041 & G322710 & $100-\mathbf{1 3 3 . 8}-150$ & $2.5-3.8-5$ & & KM030112 & KM030136 \\
\hline GW18429 & G303302 & 100-135.4-155 & $5-5.8-7.5$ & $\begin{array}{l}\text { Northern Territory, } \\
\text { Australia }\end{array}$ & $\mathrm{XX}$ & $\mathrm{XX}$ \\
\hline GW 18478 & G313113 & $105-143-185$ & $5-6.5-7.5$ & $\begin{array}{l}\text { Pulau Tembakul } \\
\text { Singapore }\end{array}$ & $\mathrm{XX}$ & $\mathrm{XX}$ \\
\hline
\end{tabular}

...Continued on next page 
TABLE 1. (Continued)

\begin{tabular}{|c|c|c|c|c|c|c|}
\hline $\begin{array}{l}\text { Voucher } \\
\text { Numbers }\end{array}$ & Museum code & Length $(\mu \mathrm{m})$ & Width $(\mu \mathrm{m})$ & Localities & $\begin{array}{l}\text { Cox2 } \\
\text { Genbank } \\
\text { accession } \\
\text { numbers }\end{array}$ & $\begin{array}{l}\text { 28S rDNA } \\
\text { Genbank } \\
\text { accession } \\
\text { numbers }\end{array}$ \\
\hline GW18491 & G313297 & $105-126.4-150$ & $5-6.4-7.5$ & Vaipuaa, Tonga & $\mathrm{XX}$ & $\mathrm{XX}$ \\
\hline GW18598 & G306321 & 74-104-130 & $5-6-7.5$ & Ongiangiang, Palau & $\mathrm{XX}$ & $\mathrm{XX}$ \\
\hline GW18777 & G311804 & $105-128.6-155$ & $5-7.4-7.5$ & $\begin{array}{l}\text { Motupure Island } \\
\text { Papua New Guinea }\end{array}$ & $\mathrm{XX}$ & $\mathrm{XX}$ \\
\hline GW18804 & G312397 & $105-123.4-150$ & $5-5.5-7.5$ & Western Australia & XX & $\mathrm{XX}$ \\
\hline GW4870 & ZMA POR16482 & $100-\mathbf{1 1 3 . 8}-170$ & $5-5.2-7.5$ & $\begin{array}{l}\text { Ryukyu Island, } \\
\text { Japan }\end{array}$ & $\mathrm{XX}$ & $\mathrm{XX}$ \\
\hline GW4811 & ZMA POR16473 & $100-\mathbf{1 2 1 . 8}-145$ & $2.5-4.9-5$ & $\begin{array}{l}\text { Koror Islands, } \\
\text { Palau }\end{array}$ & $\mathrm{XX}$ & $\mathrm{XX}$ \\
\hline GW4828 & ZMA POR21753 & $100-143-175$ & $5-5.38-7.5$ & $\begin{array}{l}\text { Busuanga Island, } \\
\text { the Philippines }\end{array}$ & $\mathrm{XX}$ & $\mathrm{XX}$ \\
\hline GW4829 & ZMA POR21752 & $105-\mathbf{1 4 5 . 4}-175$ & $5-6.1-7.5$ & $\begin{array}{l}\text { Busuanga Island, } \\
\text { the Philippines }\end{array}$ & $\mathrm{XX}$ & $\mathrm{XX}$ \\
\hline GW4866 & ZMA POR17251 & 115-158.8-190 & $7.5-8.1-10$ & Mauritius & $\mathrm{XX}$ & $\mathrm{XX}$ \\
\hline GW4867 & ZMA POR17229 & $100-132.2-165$ & $5-5.7-7.5$ & $\begin{array}{l}\text { Makassar, South } \\
\text { Sulawesi }\end{array}$ & $\mathrm{XX}$ & $\mathrm{XX}$ \\
\hline
\end{tabular}

The difference between spicule widths of the type specimen of $N$. pandora and collected samples from the GBR localities might be affected by silica influxes as recognized for other demosponges (e.g., Bavestrello et al . 1993, Maldonado et al. 1999, Stone 1970, Uriz et al. 2003, Zea and van Soest, 1986). Currently, we still need an additional support from molecular analyses for resurrecting $N$. pandora as a distinct species from the others Neopetrosia spp., and as a valid species with a distinctive skeleton and thinner oxeas. Conversely, the GBR samples, which possess a similar skeleton structure and sequence types (partial cox 2 mtDNA and 28S rDNA genes) to the other type specimens of $N$. chaliniformis, $N$. exigua, and $N$. pacifica could not be defined and raised as a new species, and are retained within this species-group. This finding also contradicts previous studies, which placed $N$. chaliniformis as a different species to $N$. exigua with $X$. pacifica as its junior synonym due to similarity of morphological characters, particularly spicules (Van Soest et al. 2017).

Identifying and recognizing the different haplosclerid sponges in the field is less problematic than the identification of small, preserved museum samples and the link to existing species based on incomplete and old descriptions like $N$. chaliniformis and $N$. exigua. Molecular markers are indispensable for this purpose and also in this case facilitated the identification of a common species.

Further attempts are required to obtain $28 \mathrm{~S}$ rDNA sequences from the $N$. chaliniformis, $N$. exigua and $N$. pandora holotypes in addition to a cox 2 sequence from $N$. pandora holotype. This will contribute to "the bottom up strategy" (see review in Cárdenas et al. 2012) in the phylogenetic study of haplosclerids since the genus Neopetrosia is still recovered as a polyphyletic group (Redmond et al. 2013, Redmond et al. 2011, Thacker et al. 2013). The bottom up strategy helps taxonomists with the revision or "re-evaluation (as the best alternative) of morphological characters under the light of molecular results" (studying type species of each haplosclerid sponge genus first) to resolve the discrepancies between current morphology and phylogeny in haplosclerids. 


\section{Acknowledgements}

ES acknowledges Naturalis Biodiversity Center, Leiden, The Netherlands for Martin Fellowship research grant and The German Academic Exchange Service (DAAD) for PhD long term scholarship. Further appreciation is also given to Ratih Aryasari (Gadjah Mada University, Yogyakarta, Indonesia) for her assistance in collecting fresh samples, in addition to Gabriele Büttner, Simone Schätzle, and Alexandra Scherer (Molecular Palaeobiology Lab, LMU Munich, Germany) for their assistance in molecular and microtechnique works. This project benefited from funding by the LMU Munich's Institutional Strategy LMUexcellent within the framework of the German Excellence Initiative to GW. Moreover, ES acknowledged Carsten Lüter (Naturkunde Museum Berlin), E. Sherlock (BMNH Museum), W.Moser (USNM Museum), S. Keable (Australian Museum Sydney) for getting access on holotype specimen examination. The Queensland Museum Brisbane is acknowledged for providing part of the specimens used in our analyses, and John Hooper is thanked for permission to publish in situ photographs used in Figure 4 A-C.

\section{References}

Abdillah, S., Nurhayati, A.P.D., Nurhatika, S., Setiawan, E. \& Heffen, W.L. (2013a) Cytotoxic and antioxidant activities of marine sponge diversity at Pecaron Bay Pasir Putih Situbondo East Java, Indonesia. Journal of Pharmacy Research, 6, $685-689$. https://doi.org/10.1016/j.jopr.2013.07.001

Abdillah, S., Wahida-Ahmad, R., Kamal-Muzaki, F. \& Mohd-Noor, N. (2013b) Antimalarial activity of Neopetrosia exigua extract in mice. Journal of Pharmacy Research, 6, 799-803. https://doi.org/10.1016/j.jopr.2013.08.001

Akaike, H. (1974) A new look at the statistical model identification. Automatic Control, IEEE Transactions on, 19, 716-723. https://doi.org/10.1109/TAC.1974.1100705

Amir, I. (1992) A comparison of sponge fauna of exposed and sheltered reef flats in eastern Indonesia. Marine Resources in Indonesia, 28, 1-12. https://doi.org/10.14203/mri.v28i0.411

Bavestrello, G., Bonito, M. \& Sara, M. (1993) Influence of depth on the size of sponge spicules. Scientia Marina, 57 (4), $415-$ 420.

Bergquist, P.R. (1965) The sponges of Micronesia, Part I. The Palau archipelago. Pacific Science, 19, $123-204$. https://doi.org/10125/4411

Borchiellini, C., Chombard, C., Manuel, M., Alivon, E., Vacelet, J. \& Boury-Esnault, N. (2004) Molecular phylogeny of Demospongiae: implications for classification and scenarios of character evolution. Molecular Phylogenetics and Evolution, 32, 823-837. https://doi.org/10.1016/j.ympev.2004.02.021

Cárdenas, P., Pérez, T. \& Boury-Esnault, N. (2012) Sponge systematics facing new challenges. In: Becerro, M.A., Uriz, M.J., Maldonado, M. \& Turon, X. (Eds.), Advances in Marine Biology. Academic Press, London, pp. 79-209. https://doi.org/10.1016/B978-0-12-387787-1.00010-6

Chombard, C., Boury-Esnault, N. \& Tillier, A. (1998) Reassessment of homology of morphological characters in tetractinellid sponges based on molecular data. Systematic Biology, 47, 351-366. https://doi.org/10.1080/106351598260761

Darriba, D., Taboada, G.L., Doallo, R. \& Posada, D. (2012) jModelTest 2: more models, new heuristics and parallel computing. Nature Methods, 9, 772-772. https://doi.org/10.1038/nmeth.2109

de Almeida Leone, P., Carroll, A.R., Towerzey, L., King, G., McArdle, B.M., Kern, G., Fisher, S., Hooper, J.N.A. \& Quinn, R.J. (2008) Exiguaquinol: a novel pentacyclic hydroquinone from Neopetrosia exigua that inhibits Helicobacter pylori MurI. Organic Letters, 10, 2585-2588. https://doi.org/10.1021/ol800898z

De Laubenfels, M.W. (1954) The Sponges of the West-Central Pacific. In: Oregon State Monographs, Studies Zoology. Oregon State College, Corvallis, pp. 1-306. https://doi.org/10.5962/bhl.title.6516

de Voogd, N.J. (2004) Callyspongia (Euplacella) biru spec.nov. (Porifera: Demospongiae: Haplosclerida) from Indonesia. Zoologische Mededelingen Leiden, 78, 477-483.

de Voogd, N.J., Becking, L.E., Hoeksema, B., Noor, A. \& Van Soest, R.W.M. (2004) Sponge interactions with spatial competitors in the spermonde archipelago. Bollettino Museo Istituti Universita Genova, 68, 253-261.

de Voogd, N.J. \& Cleary, D.F.R. (2008) An analysis of sponge diversity and distribution at three taxonomic levels in the 
Thousand islands/Jakarta bay reef complex, West-Java, Indonesia. Marine Ecology, 29, 205-215.

https://doi.org/10.1111/j.1439-0485.2008.00238.x

de Voogd, N.J. \& van Soest, R.W.M. (2002) Indonesian sponges of the genus Petrosia Vosmaer (Demospongiae: Haplosclerida). Zoologische Mededelingen, 76, 1-16.

de Weerdt, W.H. (1985) A systematic revision of the north-eastern Atlantic shallow-water Haplosclerida (Porifera, Demospongiae), Part I: Introduction Oceanapiidae and Petrosiidae. Beaufortia, 35, 61-91.

de Weerdt, W.H. \& van Soest, R.W.M. (2001) Haliclona (Halichoclona) vanderlandi spec. nov (Porifera: Demospongiae: Haplosclerida) from Indonesia. Zoologische Verhandelingen Leiden, 334, 189-194.

Desqueyroux-Faundez, R. \& Valentine, C. (2002) Family Petrosiidae Van Soest, 1980. In: Hooper, J.N.A \& van Soest, R.W.M (Eds.), Systema Porifera: a guide to the classification of sponges. Kluwer Academic/Plenum Publishers, New York, pp. 906-917.

Drummond, A.J., Ashton, B., Buxton, S., Cheung, M., Cooper, A., Duran, C., Field, M., Heled, J., Kearse, M., Markowitz, S., Moir, R., Stones-Havas, S., Sturrock, S., Thierer, T. \& Wilson, A. (2014) Geneious. Version 6.1.7 created by Biomatters. Available from: http://geneious.com (accessed 1 April 2014)

Edgar, R.C. (2004) MUSCLE: multiple sequence alignment with high accuracy and high throughput. Nucleic Acids Research, $32,1792-1797$. https://doi.org/10.1093/nar/gkh340

Flot, J.F. (2010) Seqphase: a web tool for interconverting phase input/output files and fasta sequence alignments. Molecular Ecology Resources, 10, 162-166. https://doi.org/10.1111/j.1755-0998.2009.02732.x

Gouy, M., Guindon, S. \& Gascuel, O. (2010) SeaView Version 4: A Multiplatform Graphical User Interface for Sequence Alignment and Phylogenetic Tree Building. Molecular Biology and Evolution, 27, 221-224. https://doi.org/10.1093/molbev/msp259

Hooper, J.N.A. \& van Soest, R.W.M. (2002) Systema Porifera: a guide to the classification of sponges: Kluwer Academic/ Plenum Publishers, New York, 1101 pp.

International Code of Zoological Nomenclature (ICZN) (2015) Available from: http://www.iczn.org/iczn/index.jsp (accessed 12 April 2014)

Kelly-Borges, M. \& Bergquist, P.R. (1988) Sponges from Motupore Island, Papua New Guinea. Indo-Malayan Zoology, 5, 121-159.

Kirkpatrick, R. (1900) On the sponges of Christmas Island. Proceedings of the Zoological Society of London, 1900, 127-141, pls. XII-XIII.

Liu, H., Mishima, Y., Fujiwara, T., Nagai, H., Kitazawa, A., Mine, Y., Kobayashi, H., Yao, X., Yamada, J., Oda, T. \& Namikoshi, M. (2004) Isolation of araguspongine M, a new stereoisomer of an araguspongine/xestospongin alkaloid, and dopamine from the marine sponge Neopetrosia exigua collected in Palau. Marine Drugs, 2, 154-163. https://doi.org/10.3390/md204154

Maldonado, M., Carmona, M.C., Uriz, M.J. \& Cruzado, A. (1999) Decline in mesozoic reef-building sponges explained by silicon limitation. Nature, 401, 785-788. https://doi.org/10.1038/44560

Morrow, C. \& Cárdenas, P. (2015) Proposal for a revised classification of the Demospongiae (Porifera). Frontiers in Zoology, 12 (7). [published online] https://doi.org/10.1186/s12983-015-0099-8

Orabi, K.Y., El-Sayed, K.A., Hamann, M.T., Dunbar, D.C., Al-Said, M.S., Higa, T. \& Kelly, M. (2002) Araguspongines K and $\mathrm{L}$, new bioactive Bis-1-oxaquinolizidine N-oxide alkaloids from Red Sea specimens of Xestospongia exigua. Journal of Natural Products, 65, 1782-1785. https://doi.org/10.1021/np0202226

Porebski, S., Bailey, L.G. \& Baum, B. (1997) Modification of a CTAB DNA extraction protocol for plants containing high polysaccharide and polyphenol components. Plant Molecular Biology Reporter, 15, 8-15. https://doi.org/10.1007/BF02772108

Redmond, N.E., Morrow, C., Thacker, R.W., Diaz, M.C., Boury-Esnault, N., Cárdenas, P., Hadju, E., Lobo-Hadju, G., Picton, B.E., Pomponi, S.A., Kayal, E. \& Collins, A.G. (2013) Phylogeny and systematics of Demospongiae in light of new smallsubunit ribosomal DNA (18S) sequences. Integrative and Comparative Biology, 53, 388-415. https://doi.org/10.1093/icb/ict078

Redmond, N.E., Raleigh, J., van Soest, R.W.M., Kelly, M., Travers, S.A.A., Bradshaw, B., Vartia, S., Stephens, K.M. \& McCormack, G.P. (2011) Phylogenetic relationships of the marine Haplosclerida (Phylum Porifera) employing ribosomal (28S rRNA) and mitochondrial (coxl, nadl) gene sequence data. PLoS One, 6, e24344. https://doi.org/10.1371/journal.pone.0024344

Ronquist, F., Teslenko, M., van der Mark, P., Ayres, D.L., Darling, A., Höhna, S., Larget, B., Liu, L., Suchard, M.A. \& Huelsenbeck, J.P. (2012) MrBayes 3.2: Efficient bayesian phylogenetic inference and model choice across a large model space. Systematic Biology, 61, 539-542. https://doi.org/10.1093/sysbio/sys029

Rua, C.P.J., Zilberberg, C. \& Sole-Cava, A.M. (2011) New polymorphic mitochondrial markers for sponge phylogeography. 
Journal of the Marine Biological Association of the United Kingdom, 91, 1015-1022. https://doi.org/10.1017/S0025315410002122

Silvestro, D. \& Michalak, I. (2012) RaxmlGUI: a graphical front-end for RAxML. Organisms Diversity \& Evolution, 12, 335337. https://doi.org/10.1007/s13127-011-0056-0

Stamatakis, A. (2008) The RAxML 7.0.4 manual. Department of Computer Science. Ludwig-Maximilians-Universität München. Available from: http://web.natur.cuni.cz/ vlada/moltax/RAxML-Manual.7.0.4.pdf (accessed 1 April 2014)

Stamatakis, A., Hoover, P. \& Rougemont, J. (2008) A rapid bootstrap algorithm for the RAxML web servers. Systematic Biology, 57, 758-771.

https://doi.org/10.1080/10635150802429642

Stone, A.R. (1970) Seasonal variations of spicule size in Hymeniacidon perleve. Journal of the Marine Biological Association of the United Kingdom, 50, 343-348. https://doi.org/10.1017/S0025315400004562

Thacker, R.W., Hill, A.L., Hill, M.S., Redmond, N.E., Collins, A.G., Morrow, C., Spicer, L., Carmack, C.A., Zappe, M.E., Pohlman, D., Hall, C., Diaz, M.C. \& Bangalore, P.V. (2013) Nearly complete 28S rRNA gene sequences confirm new hypotheses of sponge evolution. Integrative and Comparative Biology, 53, 373-387. https://doi.org/10.1093/icb/ict071

Thiele, J. (1899) Studien über Pazifische spongien. II. Ueber einige spongien von Celebes. Zoologica. Original-Abhandlungen aus dem Gesamtgebiete der Zoologie, Stuttgart, 24 (2), 1-33, pls. I-V.

Uriz, M.J., Turon, X., Becerro, M.A. \& Agell, G. (2003) Siliceous spicules and skeleton frameworks in sponges: Origin, diversity, ultrastructural patterns, and biological functions. Microscopy Research and Technique, 62, 279-299. https://doi.org/10.1002/jemt.10395

van Soest, R.W.M. (1980) Marine sponges from Curaçao and other Caribbean localities. Part II. Haplosclerida. In: Hummelinck, P.W. \& Van der Steen, L.J. (Eds.), Uitgaven van de Natuurwetenschappelijke Studiekring voor Suriname ende Nederlandse Antillen. No. 104. Studies on the Fauna of Curaçao and other Caribbean Islands, 62 (191), pp. 1-173. Avaliable from: http://www.repository.naturalis.nl/document/550028 (accessed 11 January 2016)

van Soest, R.W.M. (1989) The Indonesian sponge fauna: A status report. Netherlands Journal of Sea Research, 23, $223-230$. https://doi.org/10.1016/0077-7579(89)90016-1

van Soest, R.W.M., Boury-Esnault, N., Hooper, J.N.A., Rützler, K., de Voogd, N.J., Alvarez, B., Hajdu, E., Pisera, A.B., Manconi, R., Schönberg, C., Klautau, M., Picton, B., Kelly, M., Vacelet, J., Dohrmann, M., Díaz, M.C., Cárdenas, P., Carballo, J.L., Rios, P. \& Downey, R. (2017) World Porifera database. Available from: http://www.marinespecies.org/ porifera/porifera.php? $\mathrm{p}=$ taxdetails\&id=194570 (accessed 12 April 2017)

van Soest, R.W.M. \& Hooper, J.N.A. (2002) Order Haplosclerida Topsent 1928. In: Hooper, J.N.A. \& Van Soest, R.M.W. (Eds.), Systema Porifera: a guide to the classification of sponges. Kluwer Academic/Plenum Publishers, New York, pp. 831-832.

van Soest, R.W.M. \& Hooper, J.N.A. (2002) Suborder Haplosclerina Topsent 1928. In: Hooper, J.N.A. \& Van Soest, R.M.W. (Eds.), Systema Porifera: a guide to the classification of sponges. Kluwer Academic/ Plenum Publishers, New York, pp. 833-834.

van Soest, R.W.M. \& Hooper, J.N.A. (2002) Suborder Petrosina-Boury Esnault and van Beveren, 1982. In: Hooper, J.N.A. \& Van Soest, R.M.W. (Eds.), Systema Porifera: Guide to the classification of sponges. Kluwer Academic/ Plenum Publishers, New York, pp. 891-892.

Vargas, S., Schuster, A., Sacher, K., Büttner, G., Schätzle, S., Läuchli, B., Hall, K., Hooper, J.N.A., Erpenbeck, D. \& Woerheide, G. (2012) Barcoding sponges: an overview based on comprehensive sampling. PLoS One, 7, e39345. https://doi.org/10.1371/journal.pone.0039345

Wiedenmayer, F. (1977) Shallow-water sponges of the western Bahamas, Birkhäuser Verlag, Basel, 287 pp. https://doi.org/10.1002/iroh.19790640411

Zea, S. \& van Soest, R.W.M. (1986) Three new species of sponges from the Colombian Caribbean. Bulletin of Marine Science, 38 (2), 355-365. 